\title{
Genetic Variability, Heritability and Genetic Advance in Chilli (Capsicum annum L.) Genotypes
}

\author{
Pragya Singh*, P.K. Jain and Anvita Sharma \\ Department of Horticulture, Jawaharlal Nehru Krishi Vishwa Vidayalay, \\ Jabalpur 482004 (MP), India \\ *Corresponding author
}

\begin{tabular}{|c|c|}
\hline & A B S T R A C T \\
\hline Keywords & \multirow{4}{*}{$\begin{array}{l}\text { The field experiment was conducted at Horticulture Complex, JNKVV, and Jabalpur } \\
\text { (M.P.) during the year } 2015-16 \text { with } 18 \text { genotypes of chilli (Capsicum annum L.) in a } \\
\text { Randomized Complete Block Design with three replications to estimate the genetic } \\
\text { variability and heritability and genetic advance for thirteen quantitative traits. Analysis of } \\
\text { variance revealed highly significant difference among the genotypes for all the characters } \\
\text { studied. The PCV was higher than the GCV for all the traits. High magnitude of PCV and } \\
\text { GCV were observed for number of fruit plant }{ }^{-1} \text { followed by average fruit weight, fruit } \\
\text { yield plant }{ }^{-1} \text {, while it was low for number of branches plant }{ }^{-1} \text {. High heritability coupled } \\
\text { with high genetic advance as percentage of mean were observed for average fruit weight, } \\
\text { number of fruit plant }{ }^{-1} \text { suggested that the predominance of additive gene action indicating } \\
\text { better scope for improvement of these traits by an effective selection programme. }\end{array}$} \\
\hline $\begin{array}{l}\text { Chilli, GCV, PCV, } \\
\text { Heritability, } \\
\text { Genetic advance. }\end{array}$ & \\
\hline Article Info & \\
\hline $\begin{array}{l}\text { Accepted: } \\
\text { 26 August } 2017 \\
\text { Available Online: } \\
\text { 10 September } 2017\end{array}$ & \\
\hline
\end{tabular}

\section{Introduction}

Chilli (Capsicum annuum L.) is one of the most important vegetables as well as spice and cash crop of India. Chilli is a member of the Solanaceae family, originated from South and Central America. Chilli is very rich source of vitamin A and C. Green fruit of chilli is one of the richest sources of antioxidant. The pungency is due to alkaloid capsaicin. The genus Capsicum consists of approximately 22 wild and 5 cultivated species, which includes $C$. annuum, $C$. baccatum, $C$. chinense, $C$. frutescens and $C$. pubenscens. Chilli has been classified under often cross pollinated crops and the extent of natural out crossing has also reported up to 66.4 per cent (Singh et al., 1994). A wide range of variability in chilli is available which provide a great scope for improving fruit yield through a systemic and planned selection programme. Burton (1953) suggested that genetic variability along with heritability should be considered for assessing the maximum and accurate effect of selection. The knowledge of nature and magnitude of genetic variability in the population is of immense value for planning of efficient breeding programme to improve the yield potential of the genotype. Heritability is the portion of phenotypic variation which is transmitted from parent to progeny. High the heritable variation, greater will be the possibility of fixing the characters by selection. Hence, heritability studies are of foremost importance to judge whether the observed variation for a particular character is due to genotype or due to environment. 
Heritability estimates may not provide clear predictability of the breeding value. Keeping in view of the above facts the present investigation was under taken with view to study the genetic variability, heritability and genetic advance for yield and yield component characters in chilli genotypes. The present study was, therefore aimed to study variability, heritability and genetic advance among 18 genotypes of chilli.

\section{Materials and Methods}

The experiment was conducted with eighteen genotypes of chilli at Horticulture complex, Maharajpur, Department of Horticulture. J.N.K.V.V. Jabalpur (M.P.) during Rabi season of 2015- 2016. The experiment was laid out in Randomized Complete Block Design (RCBD) with 18 genotypes (16 genotypes +2 checks) and three replications. The nursery was raised during first week of September and the seedlings were transplanted at a spacing of $60 \mathrm{~cm} \times 50 \mathrm{~cm}$ in a row during last week of October. Each row consisted of 8 plants, of which five competitive plants were selected at random for recording the observations on plant height at $150 \mathrm{DAT}$, no. of primary branches / plant, days to $1^{\text {st }}$ flowering, days to $50 \%$ flowering, days to $1^{\text {st }}$ picking, fruiting span, number of fruit per plant, fruit length $(\mathrm{cm})$, fruit width $(\mathrm{cm})$, average fruit weight $(\mathrm{g})$, fruit yield /plant (g), fruit yield /plot $(\mathrm{kg})$, fruit yield /ha (q).Genotypic and phenotypic coefficients of variations (GCV and PCV) heritability, genetic advance over mean were estimated by statistical analysis.

The data were statistically analyzed for computation of genetic coefficients of variation using appropriate statistical analysis. Analysis of variance was carried out as per the procedure given by Panse and Sukhatme (1985). Genotypic and phenotypic correlation coefficients of variability were estimated according to the Burton and Devane (1953).
Heritability in broad sense was estimated as per the formula given by Allard (1960). The expected genetic advance was calculated by using formula as suggested by Johnson et al., (1955).

\section{Results and Discussion}

Analysis of variance revealed significant difference among the genotypes for all the traits indicating the presence of sufficient genetic variability in the germplasm and considerable scope for their improvement.

These results are similar with the findings of Singh et al., (2013), Yatung et al., (2014), Pandit and Ahikary (2014), Janaki et al., (2015) and Patel et al., (2015) also found sufficient variations for these traits. The result of analysis of variance is presented in table 1 . The results obtained in terms of mean, range, genotypic coefficient of variation (GCV), phenotypic coefficient of variation (PCV) along with the amount of heritability (h), expected genetic advance and genetic advance as per cent of mean (GAM) are presented in table 2. A wide range of variability was exhibited by most of the traits under study (Table 2). High range of variability recorded for fruit yield plant ${ }^{-1}$ followed by days to first picking, fruiting span, number of fruit plant ${ }^{-1}$, fruit yield $\mathrm{ha}^{-1}$, plant height at 90,120, 150 DAT.

The present findings are in accordance with the earlier findings of Singh et al., (2013), Janaki et al., (2015). The phenotypic coefficient of variation (PCV) were of higher in magnitude than that of genotypic coefficient of variation (GCV) for all the characters showing that the environment had an important role in influencing the expression of the characters. The findings are in close harmony with the findings of Jyothi et al., (2011), Singh et al., (2013). The presence of high (PCV) for characters viz., number of fruit plant ${ }^{-1}$, average fruit weight, 
fruit yield plot $^{-1}$, fruit yield $\mathrm{ha}^{-1}$, fruit yield plant $^{-1}$. Similar result was also reported by Sreelathakumari and Rajamony (2004), Patel et al., (2015).

Presence of moderate (PCV) was reported for characters viz., plant height, fruit length, fruiting span, days to first picking. The findings are in accordance with the findings of Diwakar et al., (2012). Low PCV was exhibited for characters like number of branches plant $^{-1}$, days to $50 \%$ flowering, fruit width, days to first flowering. These results are quite similar to Manju and Sreelathakumari (2002), Tembhurne et al., (2008) and Wilson and Philip (2009).

Table.1 Analysis of variance for different characters in chilli

\begin{tabular}{|c|c|c|c|}
\hline Character & $\begin{array}{l}\text { Mean sum of } \\
\text { squares } \\
\text { Replications } \\
(\mathbf{d f}=2) \\
\end{array}$ & $\begin{array}{l}\text { Genotypes } \\
(\mathbf{d f}=17)\end{array}$ & $\begin{array}{l}\text { Error } \\
(\mathbf{d f}=34)\end{array}$ \\
\hline $\begin{array}{l}\text { Plant height at } 150 \\
\text { DAT }\end{array}$ & 7.200 & $224.093 * *$ & 6.199 \\
\hline $\begin{array}{l}\text { No. of primary } \\
\text { branches /plant }\end{array}$ & 14.851 & $1.551 * *$ & 0.217 \\
\hline Days to $1^{\text {st }}$ flowering & 156.351 & $23.155 * *$ & 6.293 \\
\hline $\begin{array}{l}\text { Days to } \quad 50 \% \\
\text { flowering }\end{array}$ & 6.685 & $69.992 * *$ & 14.253 \\
\hline Days to $1^{\text {st }}$ picking & 4.462 & $158.763 * *$ & 8.090 \\
\hline Fruiting span & 4.462 & $158.763 * *$ & 8.090 \\
\hline $\begin{array}{l}\text { Number of fruit per } \\
\text { plant }\end{array}$ & 36.250 & $460.709 * *$ & 33.794 \\
\hline Fruit length $(\mathrm{cm})$ & 0.925 & $8.618 * *$ & 0.755 \\
\hline Fruit width (cm) & 0.099 & $0.015^{* *}$ & 0.003 \\
\hline $\begin{array}{l}\text { Average fruit weight } \\
\text { (g) }\end{array}$ & 0.369 & $8.156^{* *}$ & 0.398 \\
\hline Fruit yield/ plant (g) & 4376.907 & $5595.351 * *$ & 363.927 \\
\hline Fruit yield/ plot (kg) & 5.810 & $6.561 * *$ & 0.322 \\
\hline Fruit yield / ha (q) & 865.935 & $711.119 * *$ & 21.076 \\
\hline
\end{tabular}

*: Significant at $5 \%$ level; **: Significant at $1 \%$ level 
Table.2 Estimates of genetic parameters of variations for various characters in chilli

\begin{tabular}{|c|c|c|c|c|c|c|c|c|c|}
\hline \multirow{2}{*}{\multicolumn{2}{|c|}{ Characters }} & \multirow{3}{*}{$\begin{array}{c}\begin{array}{c}\text { Grand } \\
\text { Mean }\end{array} \\
31.59 \\
\end{array}$} & \multicolumn{2}{|c|}{ Range } & \multicolumn{2}{|c|}{ Variation $(\%)$} & \multirow{3}{*}{$\begin{array}{c}\mathbf{h}^{2}(\mathrm{~b})(\%) \\
81.94\end{array}$} & \multirow{3}{*}{$\begin{array}{c}\text { GA } \\
6.79\end{array}$} & \multirow{3}{*}{$\begin{array}{l}\text { GAM } \\
21.49\end{array}$} \\
\hline & & & \multirow{2}{*}{$\begin{array}{l}\text { Min. } \\
20.25\end{array}$} & \multirow{2}{*}{$\begin{array}{l}\text { Max. } \\
37.22\end{array}$} & \multirow{2}{*}{$\begin{array}{l}\text { PCV } \\
12.73\end{array}$} & \multirow{2}{*}{$\begin{array}{c}\text { GCV } \\
11.53\end{array}$} & & & \\
\hline \multirow{5}{*}{ Plant height $(\mathrm{cm})$} & 30DAT & & & & & & & & \\
\hline & 60DAT & 48.26 & 35.37 & 60.53 & 13.22 & 12.38 & 87.72 & 11.53 & 23.89 \\
\hline & 90DAT & 52.73 & 41.42 & 65.63 & 14.73 & 14.30 & 94.22 & 15.08 & 28.59 \\
\hline & 120DAT & 57.14 & 47.71 & 73.43 & 13.77 & 13.42 & 94.95 & 15.39 & 26.93 \\
\hline & 150DAT & 59.75 & 46.86 & 74.21 & 15.25 & 14.64 & 92.14 & 16.85 & 28.20 \\
\hline \multicolumn{2}{|c|}{ No. of primary branches / plant } & 18.14 & 16.87 & 19.60 & 4.48 & 3.68 & 67.18 & 1.13 & 6.21 \\
\hline \multicolumn{2}{|c|}{ Days to $1^{\text {st }}$ flowering } & 35.65 & 32.00 & 42.00 & 9.68 & 6.65 & 47.17 & 3.35 & 9.41 \\
\hline \multicolumn{2}{|c|}{ Days to $50 \%$ flowering } & 59.24 & 53.33 & 67.00 & 9.67 & 7.28 & 56.59 & 6.68 & 11.28 \\
\hline \multicolumn{2}{|l|}{ Days to $1^{\text {st }}$ picking } & 67.98 & 62.00 & 83.67 & 11.23 & 10.42 & 86.13 & 13.55 & 19.93 \\
\hline \multicolumn{2}{|l|}{ Fruiting span } & 74.02 & 58.33 & 80.00 & 10.32 & 9.57 & 86.13 & 13.55 & 18.30 \\
\hline \multicolumn{2}{|c|}{ Number of fruit per plant } & 42.20 & 22.00 & 67.00 & 31.44 & 28.26 & 80.80 & 22.09 & 52.34 \\
\hline \multicolumn{2}{|l|}{ Fruit length $(\mathrm{cm})$} & 12.72 & 7.34 & 15.12 & 14.44 & 12.72 & 77.64 & 2.94 & 23.10 \\
\hline \multicolumn{2}{|l|}{ Fruit width $(\mathrm{cm})$} & 0.99 & 0.87 & 1.16 & 8.66 & 6.56 & 57.42 & 0.10 & 10.28 \\
\hline \multicolumn{2}{|c|}{ Average fruit weight $(\mathrm{g})$} & 5.73 & 3.70 & 10.97 & 30.15 & 28.06 & 86.65 & 3.08 & 53.78 \\
\hline \multicolumn{2}{|l|}{ Fruit yield /plant (g) } & 228.35 & 166.67 & 315.00 & 20.10 & 18.29 & 82.73 & 78.25 & 34.27 \\
\hline \multicolumn{2}{|c|}{ Fruit yield /plot (kg) } & 7.41 & 5.30 & 10.06 & 20.92 & 19.46 & 86.57 & 2.76 & 37.30 \\
\hline \multicolumn{2}{|l|}{ Fruit yield /ha (q) } & 77.14 & 55.17 & 104.69 & 20.54 & 19.66 & 91.61 & 29.90 & 38.76 \\
\hline
\end{tabular}

Where: GCV - genotypic coefficient of variation, PCV - phenotypic coefficient of variation, $\mathrm{h}^{2}$ (b) - heritability in broad sence, GA - genetic advance and GAM genetic advance as percent of mean 
High heritability coupled with high genetic advance as percentage of mean were observed for number of fruit plant ${ }^{-1}$, fruit yield plant ${ }^{-1}$ (g), fruit yield $\mathrm{ha}^{-1}$ (q) suggested that the preponderance of additive genes. The results were in consonance with Varkey et al., (2005), Vani et al., (2007) and Tembhurne et al., (2008) for number of fruit plant ${ }^{-1}$, Jyothi et al., (2011) for number of fruit plant ${ }^{-1}$, Shirshat et al., (2007) for fruit yield ha ${ }^{-1}$, fruit yield plant ${ }^{-1}$. Higher estimates of heritability of the above characters might be due to additive gene effect. So, these characters could be considered as reliable selection indices and selection on the basis of these characters might be rewarding.

Low heritability coupled with low genetic advance as percentage of mean was observed for days to first flowering. This indicates the influence of non-additive gene action and considerable influence of environment on the expression of these traits. These traits could be exploited through manifestation of dominance and epistatic components through heterosis breeding. Hence, the breeder should adopt suitable breeding methodology to utilize both additive and non-additive gene effects simultaneously, since varietal and hybrid development will go a long way in the breeding programmes (Verma et al., 2014).

From the above discussion it may be concluded that there was a wide variability among the different genotypes for most of the characters studied. So, these genotypes may be utilized for future breeding programme. Traits identified for high heritability coupled with high genetic gain like number of fruit plant $^{-1}$ may be considered well in selection for improvement of the crop.

\section{Acknowledgement}

The author is thankful to Dean, College of Agriculture, Jabalpur, for extending the required facilities during the course of research work. It is a matter of great jubilance and privilege to express my deepest sense of ineptness and reverence to venerable Dr. P.K. Jain, University Professor and Head, Department of Horticulture, JNKVV, Jabalpur, for providing valuable suggestions.

\section{References}

Allard, R.W., 1960. Principles of Plant Breeding. J. Wiley and Sons, London. pp. 83-88.

Burton, G. W., and Devane, E. H. 1953. Estimating the heritability in tall fescue (Festuca arundinancea) from replicated clonal material. Agron J. 45: 478-481.

Diwaker, K., Vijay B, Rangare SB and Devi S. 2012. Genetic variability, heritability and correlation studies in chilli (Capsicum annuum L.). HortFlora Research Spectrum 1 (3): 248-252.

Janaki, M., Naidu L. Naram, Ramana CV., and RAO M. Paratpara 2015. Assesment of genetic variability, heritability and genetic advance for quantitative traits in chilli (Capsicum annuum L.).The bioscan10 (2):729-733.

Johnson, H.W., Robinson HFand Comstock RE 1955. Estimates of genetics and environment variability in soybean. Agron J 47: 314-318.

Jyothi, K.U., Kumari SS and Ramana CV. 2011. Variability studies in chilli (Capsicum annuum L.) with reference to yield attributes. J. Hortic. Sci. Biotechnol. 6 (2): 133-135.

Manju, P.R., and Sreelathakumary I. 2002. Genetic divergence in hot chilli (Capsicum chinease Jacq.). Capsicum and Eggplant Newsletter 23: 69-72.

Pandit, M.K., and Ahikary S. 2014.Variability and Heritability Estimates in Some Reproductive Characters and Yield in Chilli (Capsicum annuum L.). International Journal of Plant \& Soil 
Science 3 (7): XX-XX.

Panse, V.G., and Sukhatme, PV. 1985. Statistical methods for agricultural workers. Indian Council Agr. Res., New Delhi.

Patel, D.K., Patel BR., Patel JR., and Kuchhadiya V. Gopal 2015.Genetic variability and character association studies for green fruit yield and quality component traits in chilli (Capsicum annuиm L.). Electron J. Plant Breed 6(2):472-478.

Shirshat, S.S., Giritammannavar VA and Patil SJ. 2007. Analysis of genetic variability for quantitative traits in chilli. Karnataka j. Agric. Sci. 20 (1): 29-32.

Singh, S.K., Sachan CP and Dubey AK. 2013. Genetical Studies on Chilli (Capsicum annuum L.). Annals of Horticulture 6 (1): 164-169.

Singh, S.N., Shrivastava, J. P. and Ram, S. 1994.Natural out crossing in chilli. Veg. Sci., 21(2): 166-168.

Sreelathakumary, I., and Rajamony L.2004.Variability, heritability and genetic advance in chilli (Capsicum annuum L.). Journal of Tropical Agriculture 42 (1-2): 35-37.

Tembhurne, B.V., Revanappa $\mathrm{R}$ and
Kuchanur. 2008. Varietal performance, genetic variability and correlation studies in chilli (Capsicum annuum L.). Karnataka j. Agric. Sci. 21 (4): 541-543.

Vani, S.K., Sridevi O and Salimath PM. 2007.Studies on genetic variability, correlation and path analysis in chilli (Capsicum annuum L.). Annals of Biology 23 (2): 117-121.

Varkey, J., Saiyed MP, Patel JS and Patel DB. 2005. Genetic variability and heritability in chilli. J. Maharashtra Agric. Univ.30 (3): 346347.

Verma, A.K., Jyothi, Uma, K. and Rao, Dorajee, A.V.D. (2014). Genetic variability, heritability and genetic advance studies in Dolichos bean (Lablab purpureus L.) genotypes. Electron J. Plant Breed 5(2): 272-276.

Wilson, D., and Philip 2009.Genetic variability and genetic divergence in paprika (Capsicum annuum L.) ICHpp16.

Yatung, T., Dubey RK, Vikas S, Garima U and Pandey AK. 2014. Selection parameters for fruit yield and related traits in chilli (Capsicum annuum L.). Bangladesh J. Bot. 43 (3): 283-291.

\section{How to cite this article:}

Pragya Singh, P.K. Jain and Anvita Sharma. 2017. Genetic Variability, Heritability and Genetic Advance in Chilli (Capsicum annum L.) Genotypes. Int.J.Curr.Microbiol.App.Sci. 6(9): 27042709. doi: https://doi.org/10.20546/ijcmas.2017.609.333 